\title{
NITROGEN IN THE INITIAL GROWTH AND PHOTOSYNTHESIS PHOTOCHEMICAL IN Alibertia sessilis (Vell.) K. Schum
}

\author{
Cleberton Correia Santos $^{1 *}$, Rafael Chiquito da Cruz Ortega ${ }^{1}$, Juliana Milene Silvério ${ }^{1}$, Henrique Chacha Poyer ${ }^{1}$, \\ Silvana de Paula Quintão Scalon ${ }^{1}$, Maria do Carmo Vieira ${ }^{1}$ \\ ${ }^{1 *}$ Universidade Federal da Grande Dourados - UFGD, Faculty of Agricultural Science, Dourados, Mato Grosso do Sul, Brazil \\ *cleber_frs@yahoo.com.br
}

Received for publication: 20/12/2018 - Accepted for publication: 03/10/2019

\begin{abstract}
Resumo
Nitrogênio no Crescimento Inicial e Fotoquímica da Fotossíntese em Alibertia sessilis (Vell.) K. Schum. O uso de fertilizantes nitrogenados pode contribuir na produção de mudas de espécies nativas, tal como a Alibertia sessilis (Vell.) K. Schum, uma planta frutífera do Cerrado. Considerando que são escassos estudos referente à nutrição mineral para a espécie, objetivou-se avaliar o efeito do nitrogênio no crescimento e aspectos fotoquímicos da fotossíntese em A. sessilis. O experimento foi desenvolvido em vasos plásticos sob casa de vegetação, avaliando-se cinco doses de nitrogênio (ureia): $0,25,50,75$ e $100 \mathrm{mg} \mathrm{kg}^{-1}$ solo. O delineamento experimental utilizado foi em blocos casualizados, com quatro repetições. Aos 180 dias após o transplantio foram avaliadas as características morfométricas, fotoquímicas, biomassa e qualidade das mudas. A sobrevivência e diâmetro do coleto e relação altura/diâmetro das mudas não foi influenciada pelo nitrogênio. A altura máxima foi de $14,38 \mathrm{~cm}$ com $54,2 \mathrm{mg} \mathrm{kg}^{-1} \mathrm{de} \mathrm{N}$. O maior número de folhas e índice de clorofila ocorreram nas mudas produzidas com doses máximas de $\mathrm{N}$. As características fotoquímicas da fotossíntese, exceto a fluorescência inicial, foram influenciadas positivamente com doses na faixa de $60-85 \mathrm{mg} \mathrm{kg}^{-1} \mathrm{de} \mathrm{N}$. A maior biomassa fresca de folhas e caule foi de 2,391 e 0,257 g/planta com 54,0 e 33,0 $\mathrm{mg} \mathrm{kg}^{-1}$ de $\mathrm{N}$, respectivamente. A análise multivariada de componentes principais explicou $79,81 \%$ da variabilidade remanescente dos dados. As mudas de $A$. sessilis responderam positivamente quanto ao crescimento inicial e biomassa na dose próxima de $50,0 \mathrm{mg} \mathrm{kg}^{-1}$ de $\mathrm{N}$.

Palavras-chave: fluorescência da clorofila- $a$, nutrição mineral, análise de componentes principais, marmelinho,
\end{abstract} qualidade de Dickson.

Abstract
The use of $\mathrm{N}$ fertilizers can contribute to seedling production in native species, such as Alibertia sessilis (Vell.) K. Schum, a fruit plant of the Cerrado ecoregion. Considering that there are few studies on mineral nutrition for this species, the aim of this study was to evaluate the effect of $\mathrm{N}$ on the growth and photosynthesis photochemical of $A$. sessilis. The experiment was carried out in plastic pots in a greenhouse with five $\mathrm{N}$ (urea) concentrations: $0,25,50,75$, and $100 \mathrm{mg} \mathrm{kg}^{-1}$. The experimental design used was a randomized block design with four repetitions. At day 180 after transplantation, morphometric and photochemical characteristics, including biomass and seedling quality, were evaluated. Seedling survival, the stem diameter of the harvest, and the height/diameter ratio were not influenced by $\mathrm{N}$. The maximum height was $14.38 \mathrm{~cm}$ with $54.2 \mathrm{~kg}^{-1} \mathrm{~N}$. The greatest number of leaves and value of the chlorophyll index were found in seedlings produced with maximum doses of $\mathrm{N}$. The photochemical characteristics of photosynthesis, except initial fluorescence, were positively influenced with $\mathrm{N}$ concentrations between $60-85 \mathrm{mg} \mathrm{kg}^{-1} \mathrm{~N}$. The largest fresh leaf and stem biomass was 2.391 and $0.257 \mathrm{~g}$ plant $^{-1}$ with 54.0 and $33.0 \mathrm{mg} \mathrm{kg}^{-1}$ of $\mathrm{N}$, respectively. The multivariate analysis of the major components explained $79.81 \%$ of the remaining data variability. The seedlings of A. sessilis responded positively during the initial growth phase, reflected in their biomass, with $\mathrm{N}$ concentrations close to $50.0 \mathrm{mg}$ $\mathrm{kg}^{-1}$.

Keywords: chlorophyll- $a$ fluorescence, mineral nutrition, principal components analysis, marmelinho, Dickson quality index.

\section{INTRODUCTION}

Alibertia sessilis (Vell.) K. Schum, commonly known as marmelinho or marmelada de cachorro (Rubiaceae), is a native fruit tree species of the Cerrado ecoregion in Brazil and has subtree size. The leaves of $A$. sessilis serve as food for animals and its branches are used to make poultices, compresses, and bathing solutions, while its wood is used for firewood and charcoal (LORENZI, 2002). Lyoniresinol and 3 $\alpha$-O- $\beta$-glucopyranoside have been found in A. sessilis branch extracts (SILVA et al., 2006). Furthermore, ethanolic branch extracts have 
been found to present antifungal activity, controlling the growth of Cladosporium cladosporioides and Cladosporium sphaerospermum (SILVA et al., 2007).

In addition, $A$. sessilis seedlings can be used in recovery efforts aimed at restoring ecosystem functions in areas degraded by anthropogenic activity. From an economic standpoint, A. sessilis can be inserted in the production chain, considering the added value of using its fruits in the preparation of sweets and jellies in addition to other plant organs (LORENZI, 2002). However, it is necessary to cultivate A. sessilis ex situ when considering the current agroforestry systems and commercial orchards to mitigate its potentially intensive exploitation in native areas, to conserve genetic resources, and to ensure the sustainability of natural systems.

Given this context, information regarding the initial growth of $A$. sessilis is essential since the plants must present favorable characteristics once they are transplanted in the field to promote greater survival and developmental stability. Among the factors that may influence this phase, nutritional management is important and specifically the use of $\mathrm{N}$ fertilizers because $\mathrm{N}$ participates in photochemical and metabolic activities associated with photosynthesis and vegetative growth (GHASEMI et al., 2017; TAIZ et al., 2017).

Moreover, nutrient limitation affects growth and the excitation state of the electron transport chain during photosynthetic processes via molecular mechanisms and phytohormone regulation (BECHTOLD; FIELD, 2018). Therefore, the use of $\mathrm{N}$ fertilizers may promote growth in A. sessilis, which is a species that generally presents slow growth (LORENZI, 2002). It is essential to understand nutrient utilization and the amount of $\mathrm{N}$ required by A. sessilis to achieve maximum production, the correct use and management of fertilizers, and low production costs.

Some native species have presented positive morphophysiological responses when $\mathrm{N}$ fertilizers have been added to the cultivation substrate, such as in seedlings of Peltophorum dubium (Spreng.) Taub. (CRUZ et al., 2012), Mimosa caesalpiniifolia Benth. (GONÇALVES et al., 2013), and Handroanthus serratifolia Vahl Nich. (GOULART et al., 2017).

However, no studies have found an association with $\mathrm{N}$ fertilization and the growth of $A$. sessilis, making it necessary to carry out studies related to mineral nutrition to establish appropriate silviculture practices. We hypothesized that the use of $\mathrm{N}$ fertilizer would contribute to A. sessilis growth and chlorophyll-a fluorescence. Thus, the aim of this study was to evaluate the effect of the $\mathrm{N}$ concentration on the initial growth and photosynthesis of $A$. sessilis seedlings.

\section{MATERIALS AND METHODS}

\section{General conditions, seed collection, and seedling propagation}

The experiment was carried out from June to November 2018 at the Faculty Agricultural Science of Universidade Federal da Grande Dourados (UFGD) in Dourados, Mato Grosso do Sul, Brazil (22¹1' 43.7" S and $54^{\circ} 56^{\prime} 08.5^{\prime \prime} \mathrm{W}, 452 \mathrm{~m}$ ). Plastic pots were acclimatized at $28^{\circ} \mathrm{C}$ in a greenhouse consisting of upper and lateral plastic covers and an additional upper Aluminet ${ }^{\circledR}$ screen.

Alibertia sessilis was identified and a voucher was deposited in the UFGD Herbarium under the number 5410. Ripe A. sessilis fruits were collected at random from ten matrices in a natural population (SISGEN Permit No. A9CDAAE, 10/15/2018) at the Santa Madalena Farm (1807' 03" S and 54²5' 07" W, 452 m). Soon after, the fruits were processed.

To propagate the seedlings, sowing was performed in 128-cell expanded polystyrene trays that were filled with Tropstrato ${ }^{\circledR}$ commercial substrate (Figure 1) under nursery conditions with $50 \%$ shading and daily irrigation. Seedlings were transplanted into the plastic pots when they presented a mean height of $2.0 \mathrm{~cm}$.

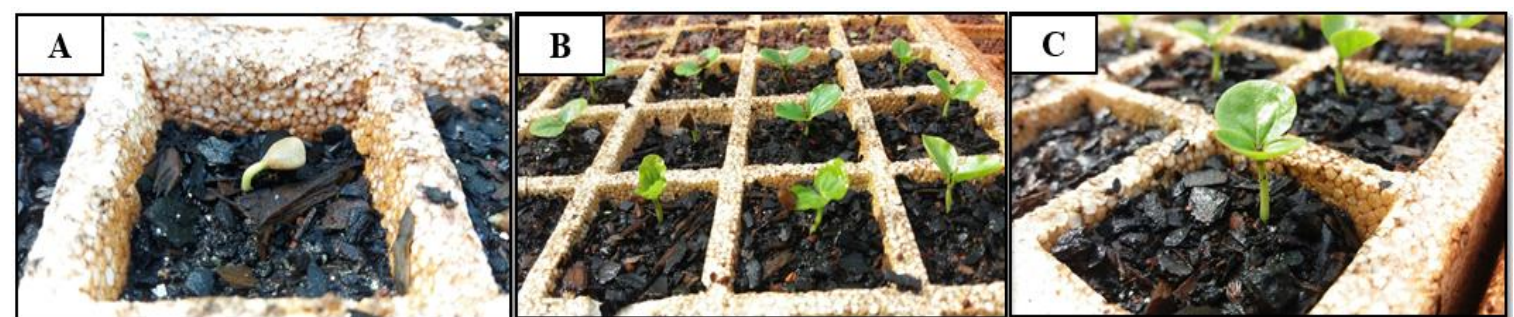

Figure 1. Emergence (A), formation (B) and growth (C) of A. sessilis seedlings produced in substrate Tropstrato ${ }^{\circledR}$. Figura 1. Emergência (A), formação (B) e crescimento (C) de mudas de A. sessilis produzidas em substrato Tropstrato $^{\circledR}$. 


\section{Experimental design and conditions}

Five N (urea: $45 \% \mathrm{~N}$ ) concentrations were included in the experiment: 0 (control), 25, 50, 75, and 100 $\mathrm{mg} \mathrm{kg}^{-1} \mathrm{~N}$. The design followed a randomized block design with four repetitions. The experimental unit consisted of four pots, with one plant each. The seedlings were grown during the initial phase in plastic pots $(5 \mathrm{~kg}$ capacity) that were filled with $4.5 \mathrm{~kg}$ Dystrophic Red Latosol of clayey texture.

Soil samples were collected to characterize their chemical attributes before starting the experiment. Soil analysis was performed and an adjustment was made using dolomitic limestone (100\% relative power of total neutralization; PRNT), a base fertilization with potassium chloride $\left(60 \% \mathrm{~K}_{2} \mathrm{O}\right)$, and simple superphosphate $(18 \%$ $\left.\mathrm{P}_{2} \mathrm{O}_{5}\right) 30$ days before seedling transplantation. The results of the soil chemical attribute characterization before liming and fertilization and at the end of the cultivation cycle (180 days after seedling transplantation) are shown in Table 1. After a 15-day transplantation period, $\mathrm{N}$ was added as a topdressing in the corresponding plots. Irrigation was performed daily with two irrigation shifts using micro-sprinklers.

Table 1. Chemical attributes of the soil used in the experiment before liming (initial) and at end of the production cycle of $A$. sessilis seedlings.

Tabela 1. Atributos químicos do solo utilizado no experimento antes da calagem (inicial) e ao final do ciclo de produção de mudas de A. sessilis.

\begin{tabular}{|c|c|c|c|c|c|c|c|c|c|}
\hline $\mathrm{pH}$ & $\mathrm{P}$ & $\mathrm{K}$ & $\mathrm{Ca}$ & $\mathrm{Mg}$ & $\mathrm{Al}$ & $\overline{\mathrm{H}+\mathrm{Al}}$ & SB & CTC & $\mathrm{V}$ \\
\hline $\mathrm{CaCl}_{2}$ & $\mathrm{mg} \mathrm{dm}^{-3}$ & \multicolumn{7}{|c|}{$\mathrm{cmol}_{\mathrm{c}} \mathrm{dm}^{-3}$} & $\%$ \\
\hline \multicolumn{10}{|c|}{ Initial } \\
\hline 4.76 & 0.51 & 0.06 & 1.04 & 0.12 & 1.20 & 7.71 & 1.22 & 8.93 & 13.68 \\
\hline \multicolumn{10}{|c|}{ End } \\
\hline 6.33 & 19.56 & 0.69 & 8.31 & 3.53 & 0.36 & 3.91 & 12.53 & 16.43 & 76.23 \\
\hline
\end{tabular}

\section{Evaluation of characteristics}

At day 180 after transplantation, plant height was evaluated with a graduated ruler $(\mathrm{mm})$ from the collect to the inflection of the highest leaf (the results expressed in $\mathrm{cm}$ ). The stem diameter ( $\mathrm{mm}$ ) of the harvest was determined with a digital caliper $( \pm 1.0 \mathrm{~cm}$ above the substrate level). The number of leaves was counted as well as the number of surviving plants. In addition, the chlorophyll index was quantified using a portable ClorofiLOG ${ }^{\circledR} /$ CFL 1030-chlorophyll meter (Falker) during the morning.

Chlorophyll-a fluorescence emissions were quantified in fully expanded leaves that were submitted to dark conditions by using leaf clips for 30 minutes between 8:00 to 10:00. Soon after, the initial $\left(\mathrm{F}_{0}\right)$, variable $\left(\mathrm{F}_{\mathrm{v}}\right)$, and maximum $\left(\mathrm{F}_{\mathrm{m}}\right)$ chlorophyll-a fluorescence and photochemical efficiency of photosystem II $\left(\mathrm{F}_{\mathrm{v}} / \mathrm{F}_{\mathrm{m}}\right)$ were determined using a portable OS-30P chlorophyll fluorometer (Opti-Sciences, Hudson, NY, USA). The efficiency of the absorbed energy $\left(\mathrm{F}_{\mathrm{v}} / \mathrm{F}_{0}\right)$ conversion and maximum non-photochemical performance $\left(\mathrm{F}_{0} / \mathrm{F}_{\mathrm{v}}\right)$ were calculated and expressed in electrons quantum ${ }^{-1}$.

Subsequently, the seedlings were harvested and separated into leaves, stems, and roots. The length of the largest root $(\mathrm{cm})$ and leaf area $\left(\mathrm{LA} ; \mathrm{cm}^{2}\right)$ were determined using a $3100 \mathrm{C}$ area meter (LI-COR, NE, USA). Biomass was determined using a precision scale $(0.0001 \mathrm{~g})$. The collected material was kept in an oven with forced air circulation at $60 \pm 5{ }^{\circ} \mathrm{C}$ until constant mass was achieved. The Dickson quality index (DQI; DICKSON et al., 1960) was also calculated using the formula: $\mathrm{DQI}=\left[\frac{\mathrm{TDB}}{\mathrm{RHD}+\mathrm{APRR}}\right]$, where RHD is the height/diameter ratio; APRR is the dry biomass aerial portion/root ratio, and TDB is total dry mass.

\section{Statistical analysis}

Survival data were transformed, $\sqrt{ }(x+0.5)$, for homogenization. ANOVA and regression analyses were performed with all the data, and $\mathrm{p}<0.05$ was considered to be statistically significant. All analyses were performed with SISVAR v. 5.6. A principal component analysis (PCA) was performed using the variance and covariance matrix considering factor scores above 0.20 using PAST v. 3.21.

\section{RESULTS}

The mean survival, harvest stem diameter, and RHD of the A. sessilis seedlings were $77.5 \%, 1.44 \mathrm{~mm}$, and 6.47, respectively, and were not influenced by the $\mathrm{N}$ concentration $(\mathrm{p}>0.05)$. The height, number of leaves,

FLORESTA, Curitiba, PR, v. 50, n. 2, p. 1379 - 1388, abr/jun 2020.

Santos, C. C. et.al.

ISSN eletrônico 1982-4688 
and chlorophyll index of $A$. sessilis plants were influenced by the $N$ concentration $(p<0.05)$, although a maximum height of $12.03 \mathrm{~cm}$ was observed with the addition of $54.22 \mathrm{mg} \mathrm{kg}^{-1} \mathrm{~N}$ (Figure 2A). The greatest number of leaves was 13.5 and was observed with $100 \mathrm{mg} \mathrm{kg}^{-1} \mathrm{~N}$ (Figure 2B). The highest relative chlorophyll index (35, Falker) occurred in plants cultivated with $100 \mathrm{mg} \mathrm{kg}^{-1} \mathrm{~N}$ (Figure 2C).
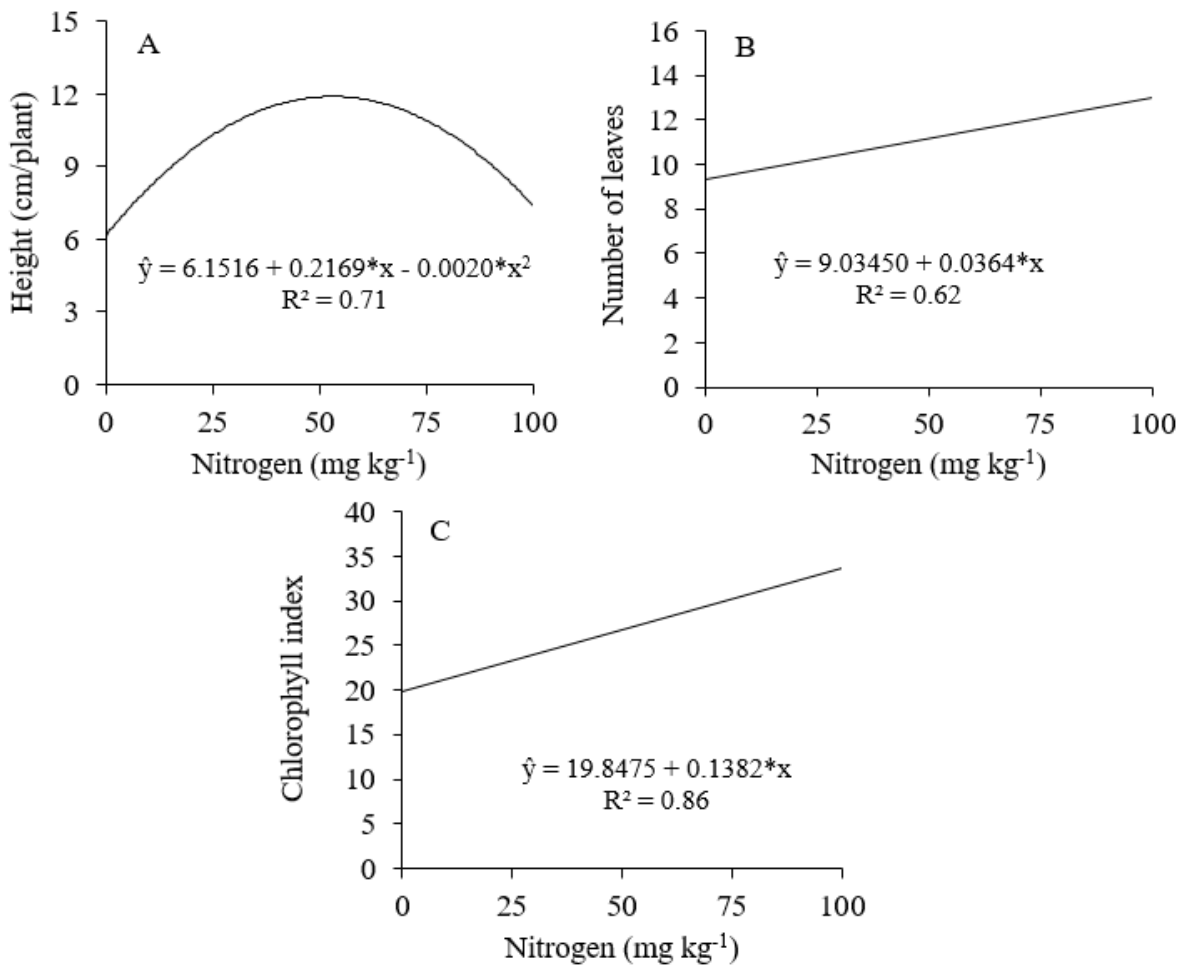

Figure 2. Height (A), number of leaves (B) and chlorophyll index (C) of A. sessilis produced with doses nitrogen. $*(\mathrm{p}<0.05)$

Figura 2. Altura (A), número de folhas (B) e índice de clorofila (C) de A. sessilis produzidas com doses de nitrogênio. * $(\mathrm{p}<0,05)$

The photochemical characteristics, except that of $\mathrm{F}_{0}$, were influenced by the $\mathrm{N}$ concentration, with a mean of 0.143 electrons quantum ${ }^{-1}$. The maximum $F_{m}\left(0.546\right.$ electrons quantum $\left.{ }^{-1}\right)$ and $F_{v}\left(0.390\right.$ electrons quantum $\left.^{-1}\right)$ values occurred in the leaves of seedlings produced with 61.66 and $60.00 \mathrm{mg} \mathrm{kg}^{-1} \mathrm{~N}$, respectively (Figure $3 \mathrm{~A}$ and B). It was found that the maximum $\mathrm{F}_{\mathrm{v}} / \mathrm{F}_{0}$ and $\mathrm{F}_{0} / \mathrm{Fv}$ ratios were 2.722 and 0.353 electrons quantum ${ }^{-1}$ with 84.25 and $68.00 \mathrm{mg} \mathrm{kg}^{-1} \mathrm{~N}$, respectively (Figure 3C and 3D). The maximum photochemical efficiency of the photosystem II $\left(\mathrm{F}_{\mathrm{v}} / \mathrm{F}_{\mathrm{m}}\right)$ was 0.728 electrons quantum ${ }^{-1}$ with $65.00 \mathrm{mg} \mathrm{kg}^{-1}$ of $\mathrm{N}$ (Figure $3 \mathrm{E}$ ). 

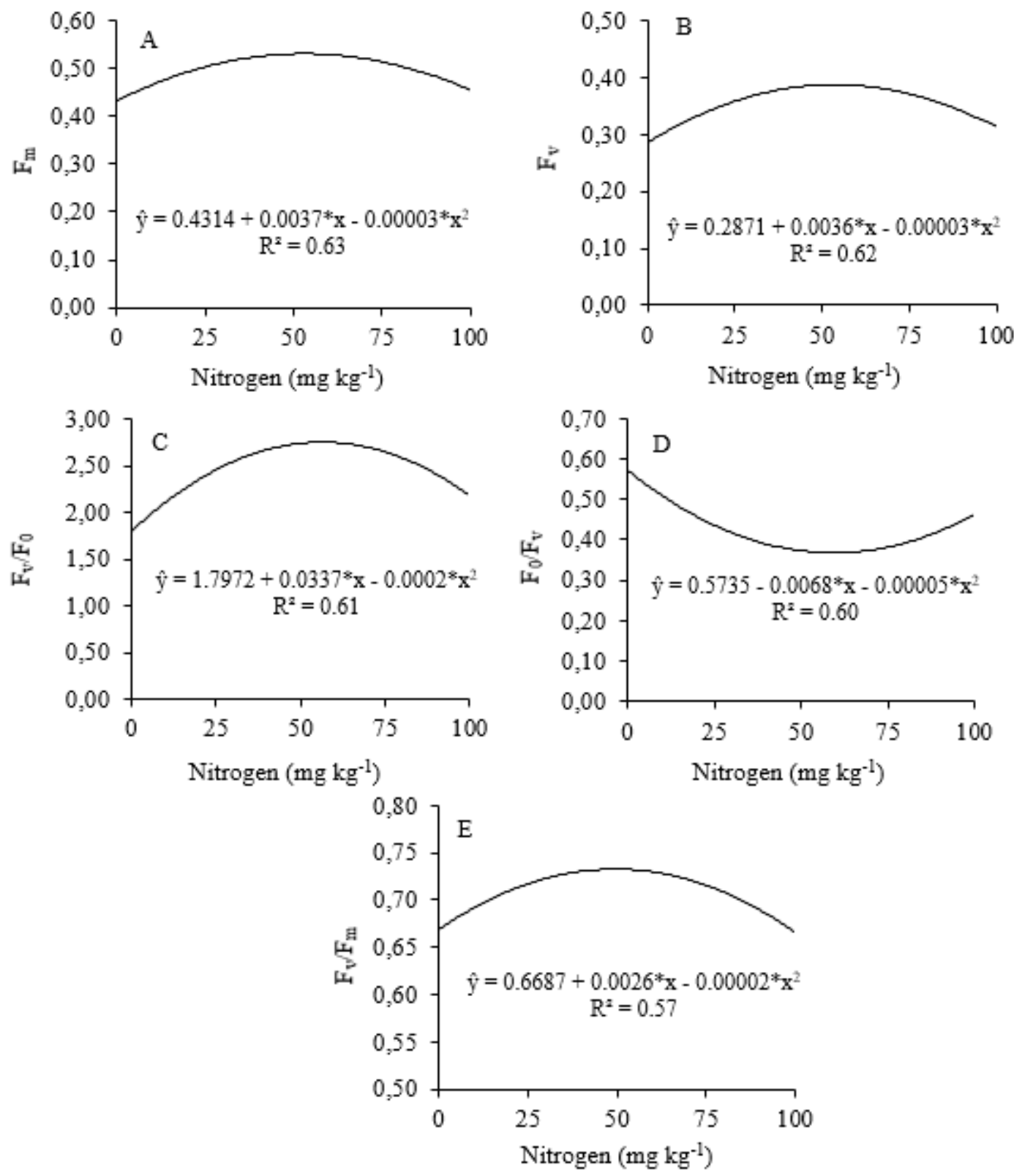

Figure 3. Maximum (A) and variable fluorescence $(B)$, absorbed energy conversion $\left(F_{v} / F_{0}\right)(C)$, maximum nonphotochemical yield $\left(\mathrm{F}_{0} / \mathrm{F}_{\mathrm{v}}\right)(\mathrm{D})$ and photochemical efficiency of photosystem II $\left(\mathrm{F}_{\mathrm{v}} / \mathrm{F}_{\mathrm{m}}\right)(\mathrm{E})$ in leaves of A. sessilis produced with doses nitrogen. * $(\mathrm{p}<0.05)$

Figura 3. Fluorescências máxima $(A)$ e variável $(B)$, conversão de energia absorvida $\left(F_{v} / F_{0}\right)(C)$, rendimento máximo não fotoquímico $\left(\mathrm{F}_{0} / \mathrm{F}_{\mathrm{v}}\right)(\mathrm{D})$ e eficiência fotoquímica do fotossistema II $\left(\mathrm{F}_{\mathrm{v}} / \mathrm{F}_{\mathrm{m}}\right)(\mathrm{E})$ em folhas de A. sessilis produzidas com doses de nitrogênio. * $(\mathrm{p}<0,05)$

The length of the largest root was not influenced by the $\mathrm{N}$ concentration $(\mathrm{p}>0.05)$, and the average root length was $8.29 \mathrm{~cm}$. With the addition of $53.71 \mathrm{mg} \mathrm{kg}^{-1} \mathrm{~N}$, a maximum leaf area of $102.68 \mathrm{~cm}^{2}$ plant $^{-1}$ was observed (Figure 4). 


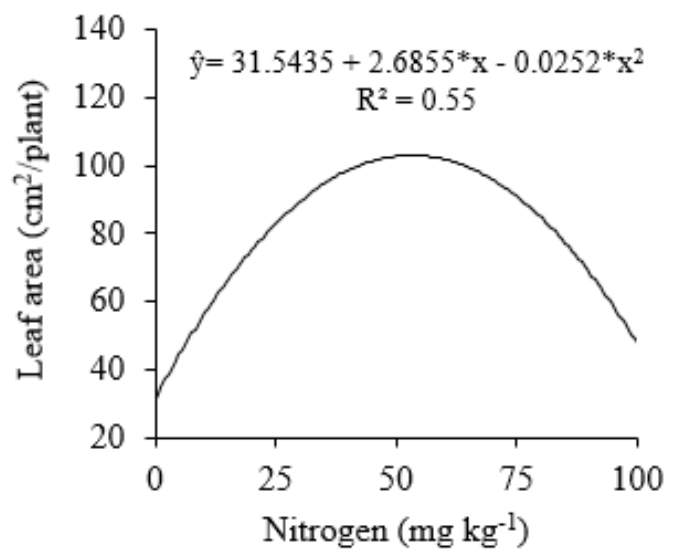

Figure 4. Leaf area in A. sessilis produced with doses nitrogen. $*(\mathrm{p}<0.05)$

Figura 4. Área foliar em A. sessilis produzidas com doses de nitrogênio. * $(\mathrm{p}<0,05)$

The largest fresh leaf and stem biomass was 2.391 and $0.257 \mathrm{~g}$ with 54.00 and $33.00 \mathrm{mg} \mathrm{kg}^{-1} \mathrm{~N}$, respectively (Figure 5A and 5B). Dry biomass was 0.697 and $0.140 \mathrm{~g}$ in seedlings produced with 75.50 and 55.00 $\mathrm{mg} \mathrm{kg}^{-1} \mathrm{~N}$, respectively (Figure 5C and 5D). On the other hand, neither fresh nor dry root biomass was influenced by the $\mathrm{N}$ concentration ( $\mathrm{p}>0.05$ ), with a mean of 0.106 and $0.049 \mathrm{~g}$, respectively.
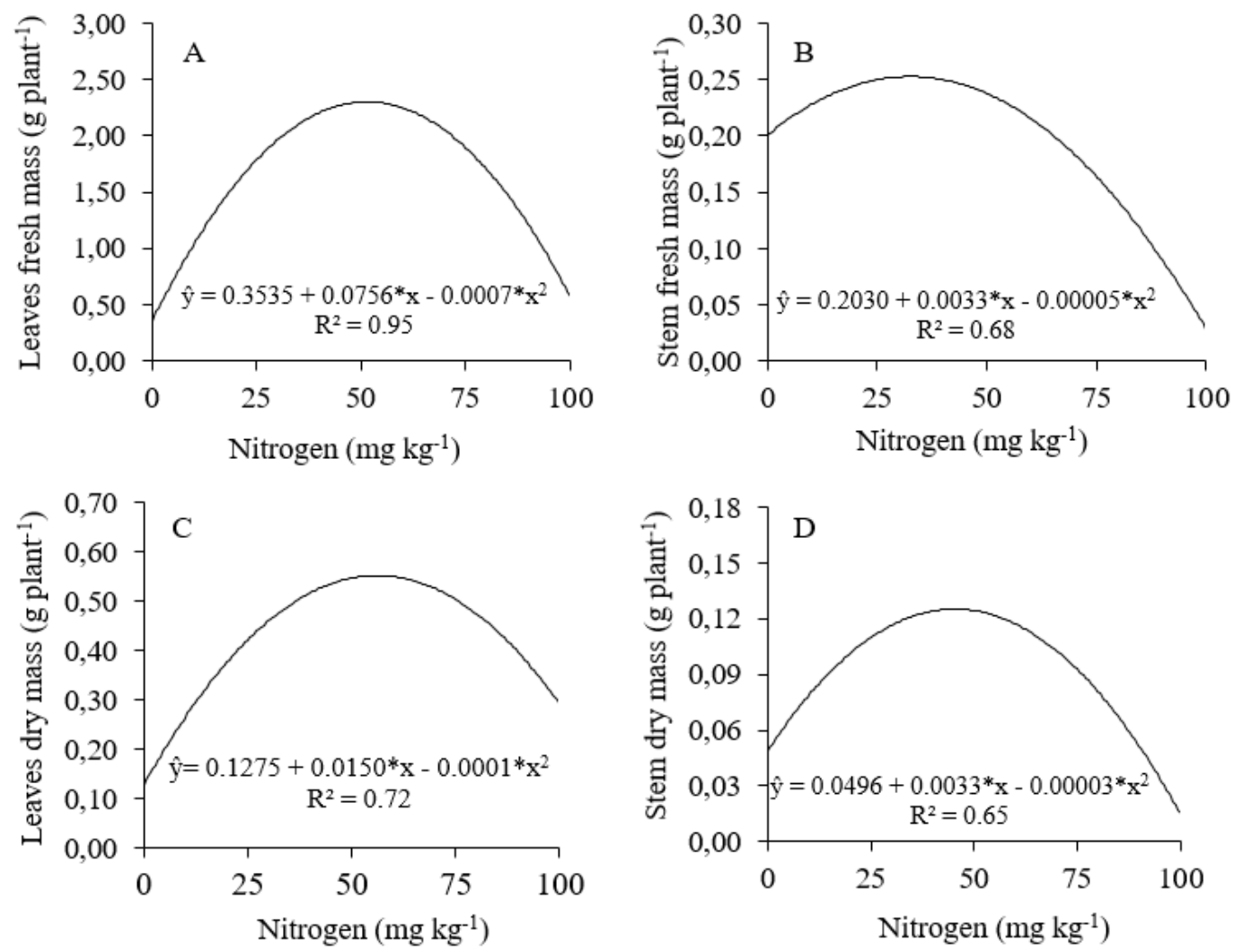

Figure 5. Leaves fresh and dry biomass $(\mathrm{A}, \mathrm{C})$ and stem $(\mathrm{B}, \mathrm{D})$ of $A$. sessilis produced with doses nitrogen. * $(\mathrm{p}<0.05)$

Figura 5. Biomassa fresca e seca de folhas (A, C) e caule (B, D) de A. sessilis produzidas com doses de nitrogênio. $*(\mathrm{p}<0,05)$

With regard to total dry biomass, the maximum value observed was $0.992 \mathrm{~g}$ plant $^{-1}$ with the addition of $51.66 \mathrm{mg} \mathrm{kg}^{-1} \mathrm{~N}$ (Figure 6A). The DQI was influenced by the $\mathrm{N}$ concentration, and the highest value $(0.15)$ was produced seedlings with $43.75 \mathrm{mg} \mathrm{kg}^{-1} \mathrm{~N}$ (Figure 6B). 

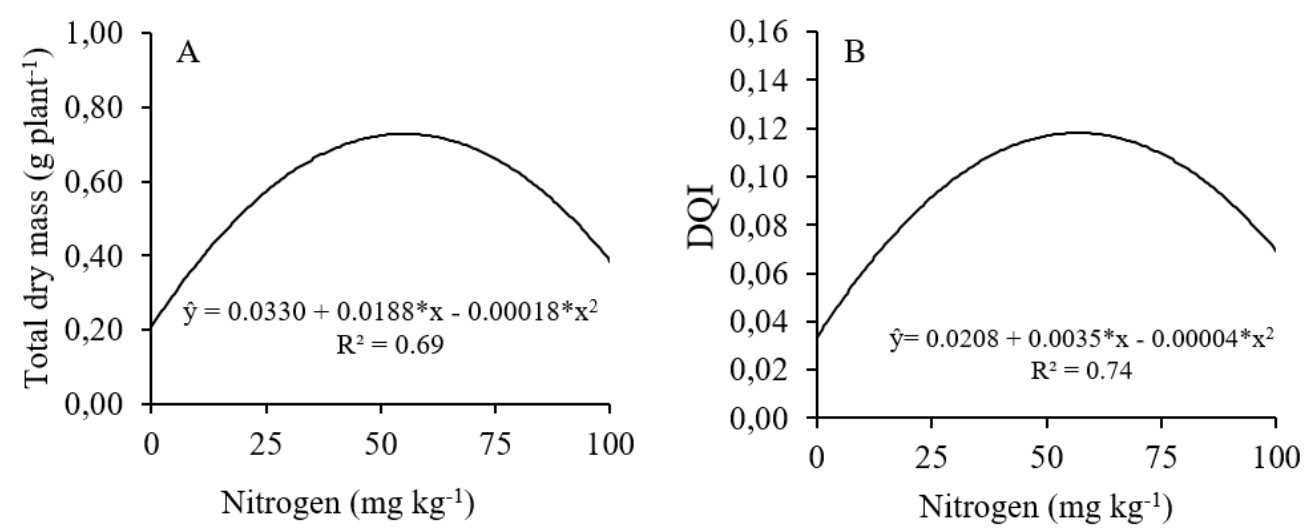

Figure 6. Total dry biomass (A) and Dickson quality index - DQI (B) of A. sessilis produced with doses nitrogen. $*(\mathrm{p}<0.05)$

Figura 6. Biomassa seca total (A) e índice de qualidade de Dickson - IQD (B) de A. sessilis produzidas com doses de nitrogênio. * $(\mathrm{p}<0,05)$

The principal component analysis (PCA) explained $79.81 \%$ of the remaining data variability, with the first (PC 1) and second (PC 2) components constituting 75.05\% and 16.66\%, respectively (Figure 7), and the characteristics of root length and fresh stem biomass were eliminated. The characteristics with higher factor scores (i.e., importance of qualitative experimental constitution) in increasing order were DQI, BSF, TDB, BFF, and $F_{m}$ in PC 1 and $F_{0}$, Survival (S), leaves number (LN), and APRR in PC 2. It can be observed that the growth, photochemical, biomass, and quality characteristics of the A. sessilis plants were associated with $\mathrm{N}$ concentrations between 25 and $50 \mathrm{mg} \mathrm{kg}^{-1}$.

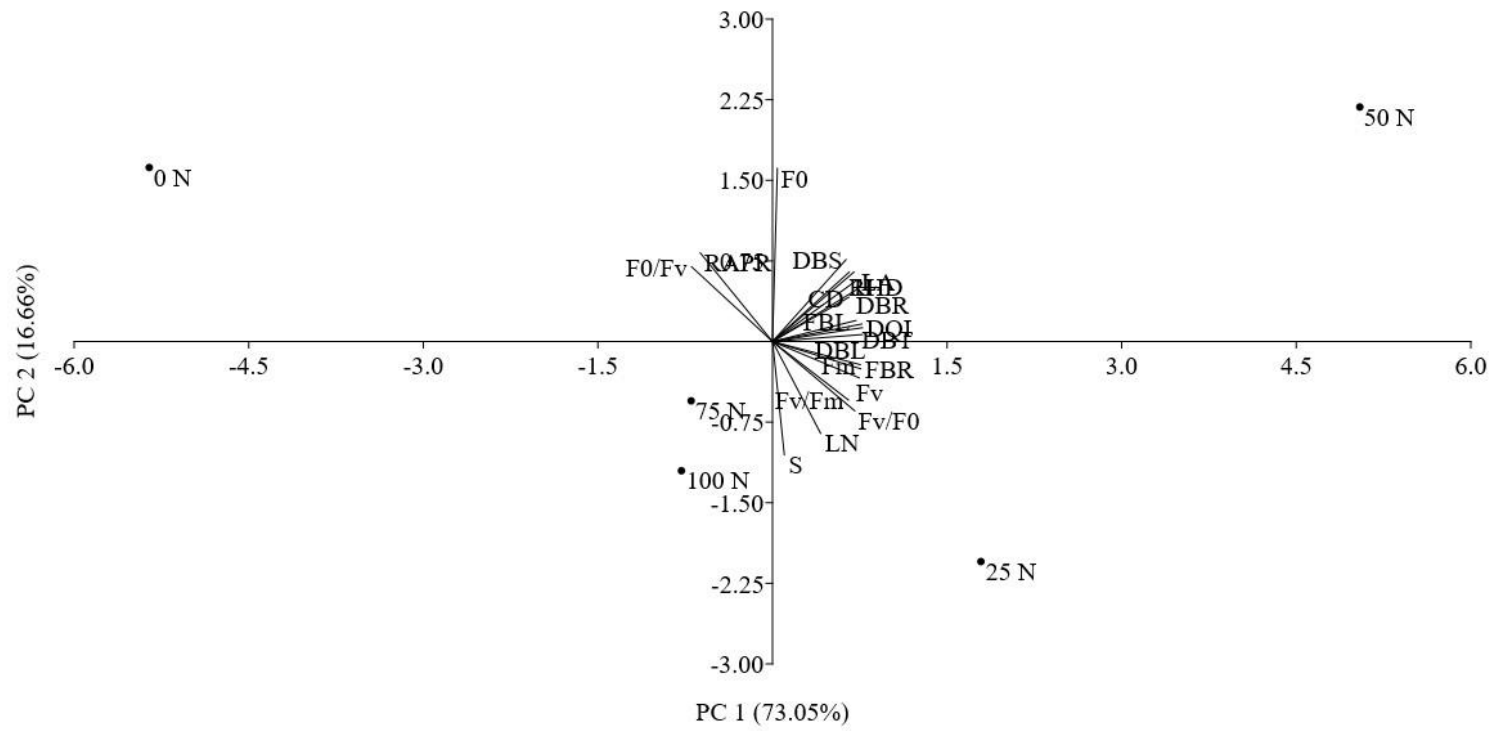

Figure 7. Principal components analysis of characteristics evaluated in plants of $A$. sessilis produced with doses nitrogen $\left(0 ; 25 ; 50 ; 75\right.$ and $\left.100 \mathrm{mg} \mathrm{kg}^{-1} \mathrm{~N}\right)$.

Figura 7. Análise de componentes principais de características avaliadas em plantas de A. sessilis produzidas com doses de nitrogênio $\left(0 ; 25 ; 50 ; 75\right.$ e $\left.100 \mathrm{mg} \mathrm{kg}^{-1} \mathrm{~N}\right)$.

\section{DISCUSSION}

It is noteworthy that during the initial experimental period (up to 60 days after transplantation), a loss of leaves in some seedlings was observed. From 80 days after transplantation, regrowth was observed that indicated the survival of the individuals as well as their morphophysiological plasticity, which is a desirable trait when aiming to re-establish areas during environmental recovery efforts. 
The height of plants in this study was higher than that found by Mota et al. (2017), who assessed the emergence and initial growth of the same species and observed heights $\sim 4.0 \mathrm{~cm}$ higher at 120 days after sowing than those in this study. The increase in the major morphometric characteristics was associated with $\mathrm{N}$ being responsible for vegetative development (RAZAC et al., 2017) given that $\mathrm{N}$ forms part of the structure of the nucleotides glutamine and glutamate, which participate in metabolic functions (TAIZ et al., 2017). Similar results were observed by Feitosa et al. (2011), who found that the maximum height of Astronium fraxinifolium Schott was obtained with the addition of $72.5 \mathrm{mg} \mathrm{kg}^{-1} \mathrm{~N}$, demonstrating that the use of $\mathrm{N}$ fertilizers contributed to initial growth but that maximum $\mathrm{N}$ concentrations were not fully used by the plants. In young Dalbergia miscolobium Benth. and Jacaranda cuspidifolia Mart. plants, an increase in height was also observed when N fertilization was performed (DUTRA et al., 2015).

The role of this nutrient in the synthesis of photosynthetic pigments (i.e., in the chlorophyll index) is associated with its participation in the central structure of the chlorophyll molecule (GHASEMI et al., 2017), which favors increased chloroplastidic content. Plants that present more pronounced visual growth and green pigmentation tend to be plants with good nutritional efficiency, especially $\mathrm{N}$ use efficiency (CIRIELLO et al., 2014), as was observed in the A. sessilis seedlings (Figure 8). The increase of this photosynthetic pigment with the addition of $\mathrm{N}$ is a desirable characteristic since it favors the production of biomass at the expense of the amount of photoassimilates that are produced (ANYCESIUM et al., 2018).

Determining the value of the chlorophyll index using portable meters is a widely accepted practice given its practicality and because it is a non-destructive method. In a study conducted by Schlichting et al. (2015), it was found that chlorophyll index values from chlorophyll meters did not differ from those obtained via a destructive laboratory extraction method, which is considered to be a reliable technique. Furthermore, the chlorophyll index has been found to be correlated with the $\mathrm{N}$ content of the plant, which indirectly provides information of the nutritional status of the plant without an assessment of extracted plant tissue (SCHLICHTING et al., 2015).

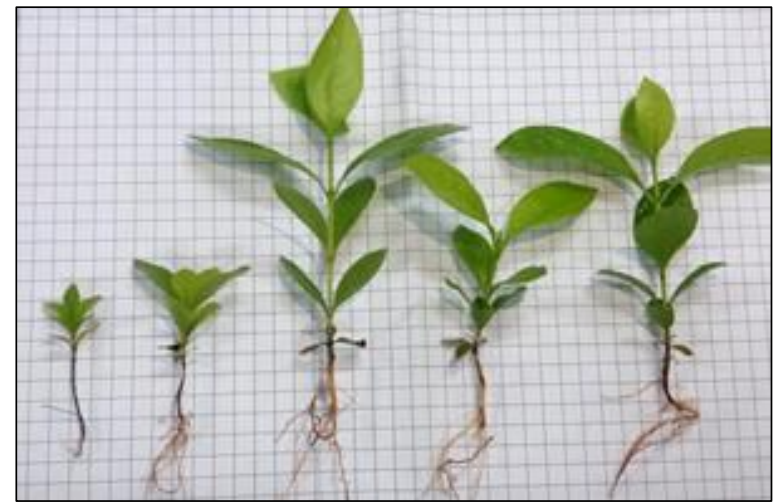

Figure 8. Visual aspect of $A$. sessilis seedlings produced with doses nitrogen $\left(0,25,50,75\right.$ and $\left.100 \mathrm{mg} \mathrm{kg}^{-1} \mathrm{~N}\right)$. Increasing doses - right to left.

Figura 8. Aspecto visual de mudas de A. sessilis produzidas com doses de nitrogênio $\left(0,25,50,75\right.$ e $100 \mathrm{mg} \mathrm{kg}^{-1}$ N). Doses crescentes - direita para esquerda.

Oliosi et al. (2017) describe that the increase in $\mathrm{F}_{0}$ represents an expected photochemical loss, which presents either no or little influence of the presence or absence of $\mathrm{N}$. In general, the benefits of $\mathrm{N}$ fertilization that are observed in photochemical parameters are associated with increased chlorophyll content, which favors synchronism between the acceptors in the electron transport chain (CENDRERO-MATEO et al., 2016). Lower photochemical values indicate harmful physiological metabolism changes given that under conditions of the absence or deficiency of $\mathrm{N}$ in photosystem reactions, enzymatic collapse occurs (mainly of ribulose 1.5 carboxylase/oxygenase; RUBISCO), causing a decrease in the maximum photosynthetic capacity and reducing the potential plant growth and biomass (HAWKESFORD et al., 2012), as was observed in this study.

The use of chlorophyll- $a$ fluorescence emission as a complementary indicator of the nutritional status of plants regarding $\mathrm{N}$ is still incipient when comparted to other nutritional diagnosis methods (ROSSATO et al., 2012); however, it may assist in decision making regarding complementary field fertilization during the cultivation cycle. Chlorophyll-a fluorescence emission has been used in the study of the photosynthetic capacity of plants and is considered to be non-destructive method that allows for both the qualitative and quantitative analysis of the absorption and use of light energy by the photosynthetic apparatus (OLIOSI et al., 2017) through the activities of the photosystem II. 
The largest leaf area observed with $53.71 \mathrm{mg} \mathrm{kg}^{-1} \mathrm{~N}$ was associated with the fact that $\mathrm{N}$ participates in the process of leaf limb expansion. This characteristic is important in determining the amount of light that the plant intercepts and directly favors diffusive metabolic processes, especially the assimilation of $\mathrm{CO}_{2}(\mathrm{MELO}-\mathrm{CRUZ}$ et al., 2012). The production of fresh biomass from different vegetative organs is related to the amount of photosynthetic active radiation that is intercepted and absorbed by the leaves and the efficiency with which they convert radiant energy into chemical energy, thereby increasing the photosynthetic rate (TAIZ et al., 2017). Thus, $\mathrm{N}$ is linked with the maximization of photosynthetic capacity, which favors biomass production (RAZAQ et al., 2017; ZEEMAN; MORGAN, 2018). In this sense, the increase in biomass is directly associated with the number of leaves and leaf area close to this dose, favoring an increase in photoassimilates.

In other studies with native Cerrado species, positive results with $\mathrm{N}$ fertilization during the initial growth phase have also been observed. Souza et al. (2013) and Gonçalves et al. (2017) evaluated Peltophorum dubium (Sprengel) Taubert and Jacaranda decurrens Sub sp. Symmetrifoliolata and observed higher dry leaf biomass yields with 62.46 and $50.00 \mathrm{mg} \mathrm{kg}^{-1} \mathrm{~N}$, respectively. The higher values of total dry biomass and DQI observed in this study are associated with the fact that $\mathrm{N}$ concentrations close to these $\left(55.0\right.$ and $58.0 \mathrm{mg} \mathrm{kg}^{-1} \mathrm{~N}$, respectively) were associated with greater growth and biomass production since the DQI is related to the architecture of the aerial portion of the plant and partition of photoassimilates, and the higher the DQI, the greater the vigor of the seedlings. Thus, good silviculture management during the nursery stage is essential to avoid losses and provide high quality plants (GOULART et al., 2017) with the aim of subsequently transplanting them into the field. However, species may respond differently to fertilization. Jesus et al. (2014) evaluated the combination of inoculation and $\mathrm{N}$ on Enterolobium contortisiliquum (Vell.) Morong seedlings and found that initial cultivation with $\mathrm{N}$ fertilization alone did not favor an increase in DQI.

With regard to the multivariate analysis, the A. sessilis seedlings that were produced with $\mathrm{N}$ addition showed a greater capacity for balanced biomass allocation among the different organs. In addition, it should be noted that all characteristics, except for the number of leaves and the chlorophyll index, showed the highest values with doses below the maximum $\mathrm{N}$ concentration, indicating that it is possible to reduce production costs with $\mathrm{N}$ fertilizers while mitigating damage to renewable natural resources due an excess nutrient supply and still obtain plants with a high quality standard. Furthermore, other studies that evaluate macro and micronutrients during the initial growth of $A$. sessilis seedlings should be carried out in the future to develop silviculture recommendations for the ex situ phase to evaluate the full cultivation potential of this species.

\section{CONCLUSION}

- $\quad \mathrm{N}$ fertilization positively influences the production of Alibertia sessilis (Vell.) Schum seedlings, and recommended concentration during the initial cultivation phase is $50 \mathrm{mg} \mathrm{kg}^{-1} \mathrm{~N}$ to obtain plants with higher standard quality.

- $\quad$ Photosynthesis photochemical efficiency was greatest with $\mathrm{N}$ fertilization concentrations between 60-85 $\mathrm{mg} \mathrm{kg}^{-1} \mathrm{~N}$.

\section{ACKNOWLEDGMENT}

The National Council for Scientific and Technological Development (CNPq) and Coordination for the Improvement of Higher Education Personnel (CAPES), for the granting of scholarships, and the Foundation for Support to the Development of Education, Science and Technology of the State of Mato Grosso do Sul (FUNDECT) for financial support.

\section{REFERENCES}

ANICÉSIO, E. C. A.; BONFIM-SILVA, E. M.; SILVA, T. J. A.; PACHECO, A. B. Nitrogênio e potássio em cártamo: índice de clorofila, características biométricas e uso da água. Revista Caatinga, Mossoró, v. 31, n. 2, p. 424-433, 2018.

BECHTOLD, U.; FIELD, B. Molecular mechanisms controlling plant growth during abiotic stress. Journal of Experimental of Botany, Oxford, v. 69, n. 11, p. 2753-2758, 2008.

CENDRERO-MATEO, M. P.; MORAN, M. S.; PAPUGA, S. A.; THORP, K. R.; ALONSO, L.; MORENO, J.; PONCECAMPOS, G.; RASCHER, U.; WANG, G. Plant chlorophyll fluorescence: active and passive measurements at canopy and leaf scales with different nitrogen treatments. Journal of Experimental Botany, Oxford, v. 67, n. 1, p. 275-286, 2016.

CIRIELLO, V.; GUERRINI, I. A.; BACKES, C. Doses de nitrogênio no crescimento e nutrição de plantas de guanandi. Cerne, Lavras, v. 20, n. 4, p. 653-660, 2014. 
CRUZ, C. A. F.; PAIVA, H. N.; CUNHA, A. C. M. C. M.; NEVES, J. C. L. Produção de mudas de canafístula cultivadas em Latossolo vermelho amarelo álico em resposta a macronutrientes. Cerne, Lavras, v. 18, n. 1, p. 87-98, 2012.

DICKSON, A.; LEAF, A. L.; HOSNER, J. F. Quality appraisal of white spruce and white pine seedling stock in nurseries. Forestry Chronicle, v. 36, n. 1, p. 10-13, 1960.

DUTRA, T. R.; MASSAD, M. D.; MATOS, P. S.; SARMENTO, M. F.; OLIVEIRA, J. C. Crescimento inicial e qualidade de mudas de caviúna-do-cerrado e caroba-do-campo em respostas à adubação nitrogenada. Agropecuária Científica no Seminário, Patos, v. 11, n. 3, p. 52-61, 2015.

FEITOSA, D. G.; MALTONI, K. L.; CASSIOLATO, A. M.; PAIANO, M. O. Crescimento de mudas de Gonçalo-alves (Astronium fraxinifolium) sob diferentes e doses de nitrogênio. Revista Árvore, Viçosa, v. 35, n. 3, p. 401-411, 2011.

GHASEMI, H.; ESMAEILLI, M. A.; MOHAMMADIAN, R. Effects of nitrogen on chlorophyll fluorescence and the relationship between chlorophyll content and SPAD values in sugar beet (Beta vulgaris L.) under drip-tape system. Journal of Agricultural and Biological Science, v. 12, n. 3, p. 117-122, 2017.

GONÇALVES, E. O.; PAIVA H. N.; NEVES, J. C. L.; GOMES, J. M. Nutrição de mudas de Mimosa caesalpiniaefolia Benth. Sob diferentes doses de N, P, K Ca e Mg. Ciência Florestal, Santa Maria, v. 23, n. 2, p. 273-286, 2013.

GONÇALVES, W. V.; VIEIRA, M. C.; CARNEVALI, T. O.; HEREDIA ZÁRATE, N. A.; ARAN, H. D. R.; MINELI, K. C. S. Nitrogen and phosphorus fertilization promotes aerial part Development and affect nutrient uptake by carobinha of the Brazilian Cerrado. American Journal of Plant Sciences, v. 8, p. 3377-3398, 2017.

GOULART, L. M. L.; PAIVA, H. N.; LEITE, H. G.; XAVIER, A.; DUARTE, M. L. Produção de mudas de ipê-amarelo (Tabebuia serratifolia) em resposta a fertilização nitrogenada. Floresta e Ambiente, Seropédica, v. 24, e00137315, p. 22-31, 2017.

HAWKESFORD, M.; HORST, W.; KICHEY, T.; LAMBERS, H.; SCHJOERRING, J.; MøLLER, I.S.; WHITE P. Functions of Macronutrients. MARSCHNER, P. (Ed.). Marschner's Mineral Nutrition of Higher Plants, 2012. p. 135189.

JESUS, A. A.; NÓBREGA, R. S. A.; NÓBREGA, J. C. A.; COSTA, E. M.; MOREIRA, F. M. S.; PACHECO, L. P. Quality of Enterolobium contortisiliquum (Vell.) Morong. seedlings in function of inoculation and natural nodulation in soils from southwest of Piauí, Brazil. Revista Ciências Agrárias, Lisboa, v. 37, n. 2, p. 198-205, 2014.

LORENZI, H. Árvores brasileiras: manual de identificação e cultivo de plantas arbóreas nativas do Brasil. vol. 2. Nova Odessa: Plantarum, 2002. 384p.

MOTA, L. H. S.; SCALON, S. P. Q.; HEINZ, R.; DRESCH, D. M. Substrates and water availability on the emergence and initial growth of Alibertia sessilis Schum. seedlings. Revista Floresta, Curitiba, v. 47, n. 4, p. 513-522, 2017.

OLIOSI, G.; RODRIGUES, J. O.; FALQUETO, A. R.; PIRES, F. R.; MONTE, J. A.; PARTELLI, F. L. Fluorescência transiente da clorofila $a$ e crescimento vegetativo em cafeeiro conilon sob diferentes fontes nitrogenadas. Coffee Science, v. 12, n. 2, p. 248-259, 2017.

RAZAQ, M.; ZHANG, P.; SHEN, H.; SALAHUDDIN. Influence of nitrogen and phosphorus on the growth and root morphology of Acer nono. PLoS ONE, v. 12, n. 2, p. e0171321, 2017.

ROSSATO, O. B.; ANDRADE-SANCHEZ, P.; GUERRA, S. P. S.; CRUSCIOL, C. A. C. Sensores de reflectância e fluorescência na avaliação de teores de nitrogênio, produção de biomassa e produtividade. Pesquisa Agropecuária Brasileira, Brasília, v. 4, n. 8, p. 1133-1141, 2012.

SCHLICHTING, A. F.; BONFIM-SILVA, E. M.; SILVA, M. C.; PIETRO-SOUZA, W.; SILVA, T. J. A.; FARIAS, L. N. Efficiency of portable chlorophyll meters in assessing the nutritional status of wheat plants. Revista Brasileira de Engenharia Agrícola e Ambiental, Campina Grande, v. 19, n. 12, p. 1148-1151, 2015.

SILVA, V. C.; BOLZANI, V. S.; YOUNG, M. C. M.; LOPES, M. N. A new antifungical phenolic glycoside derivative, iridoids and lignans from Alibertia sessilis (Vell.) K. Schum. (Rubiaceae). Journal of the Brazilian Chemical Society, v. 18, n. 7, p. 1405-1409, 2007.

SILVA, V. C.; SILVAB, G. H.; BOLZANI, V. S.; LOPES, M. N. Isolation of lignans glycosides from Alibertia sessilis (Vell.) K. Schum. (Rubiaceae) by preparative high-performance liquid chromatography. Eclética Química, Araraquara, v. 31, n. 4, p. 55-58, 2006.

SOUZA, N. H.; MARCHETTI, M. E.; CARNEVALI, T. O.; RAMOS, D. D.; SCALON, S. P. Q.; SILVA, E. F. Estudo nutricional da canafístula (I): crescimento e qualidade das mudas em resposta a adubação com nitrogênio e fósforo. Revista Árvore, Viçosa, v. 37, n. 4, p.717-724, 2013.

TAIZ, L.; ZEIGER, E.; MØLLER, I. M.; MURPHY, A. Fisiologia e Desenvolvimento Vegetal. 6. ed. Porto Alegre: Artmed, 2017, 888 p.

ZEEMAN, B. J.; MORGAN, J. W. Increasing and declining native species in urban remnant grasslands respond differently to nitrogen addition and disturbance. Annals of Botany, v. 121, n. 4, p. 691-697, 2018. 